\title{
Profitability and Efficiency of Indian Banking (A Comparative Study of Selected Public and Private Sector Banks)
}

\author{
Rahul Mathur \\ Financial Analyst at Better.com; rahulmathur490@gmail.com
}

\begin{abstract}
Banks played an un-denying relentless role in the banking system of modern India. It is not only commendable but also adorable. The efficiency of the banks is crucial for the existence of smooth flow of trade locally and internationally. It is expected that Banking institution should earn profit but also maintain reasonable level of efficiency. Profitability of banks is dependents on several variables in which efficiency is most important. In this study efforts have been made to judge profitability and efficiency of selected leading public sector and private sector bank. Profitability and efficiency of selected public and private sector banks analyzed on the basis of some important financial ratios. The current study is mainly concerned with analysis of comparative performance selected public sector and private sector banks. The results have found strong evidence that the Private Sector Banks proved their better performance on the parameters of profitability and efficiency selected for the study.
\end{abstract}

Keywords: Efficiency, Private Sector Banks, Profitability, Public Sector Banks

\section{Introduction}

An efficient banking system has significant positive externalities, which increases the efficiency of economic transaction in general. The relative efficiency of banks is a matter of concern to the all the participants, be it regulators, customer, manager and stakeholders. Profit is the main object of our society and prima facie object of every business. It is indicator of the success of business. Profit is the turn around which revolve the various activities of business. Everything in the world is result oriented and a firm too is not an exception to it. Profitability means the profit earning capacity of the enterprise and the ability of management to generate surplus in the process of business operations. It is overall assess of efficiency. Profits refer to the unlimited quantum of profits. The profitability is the most powerful motivational factor in any business. The operational efficiency of the banks determines the success or failure of the banking sector.

It is believed that private ownership helps to improve efficiency and performance of banks and accordingly, the Indian Government started diluting its equity in PSBs from early 1990s in phase manner. Growing trend of entry of more and more private banking really helped to improved efficiency and profitability of Indian Banking Sector.

\section{Need of the Study}

The intensifying competitive environment in the banking sector forcing the banks to focus in their operations. The profile of the banks, no doubt, plays an important role in the performance of the banks and measuring the 
relative profile. Various parameters have been used to determine the profile of the banks. Evaluating the profile of the commercial banks is important to depositors, owners, potential investors, managers and of course, the regulators.

\subsection{Objective of the Study}

- To identify and analyze the emerging trend and comparison of profitability of selected public sector private sector banks and

- To analyze the comparison of performance of efficiency of public and private sector banks.

\subsection{Review of Literature}

Guruswamy (2012) evaluated the profitability performance of State Bank of India and found that among the associate banks, State Bank of Patiala, State Bank of Hyderabad, State Bank of Indore and State Bank of Bikaner proved to be most dynamic in earning profit compared to State Bank of India. Kaur (2012) studied the financial performance of banks in India in view of increasing globalization and increased competition in the banking industry. He concluded that the financial position of banks is reasonable, debt equity ratio is maintained at an adequate level and NPA's also witnessed a decline during the study period. Sharma and others (2013) in their study discussed that both the frontier approaches, parametric and non-parametric, are gaining an edge over the traditional financial measures. Nedunchezhian (2016) evaluated financial performance of the Indian public sector banks. Five Indian public sector banks have been chosen for the study in the random manner. The financially stabilized manner some of the variables has been selected for the study to analyze the financial performance like Deposits, Loans, Assets, Equity shareholder capital, Return on Equity, Return on Assets and Net profit margin. Abdulkareem (2020) attempted to analyze and examine the profitability performance of two selected private banks in India; HDFC bank and ICICI bank. The article also aims to draw a comparison between the profitability performances of these two banks in order to come up with clear understanding of new banking strategies. The findings reveal that HDFC Bank is generating more profitability than ICICI bank.

\subsection{Scope of the Study}

Scope of the study is quite wider, covers the leading banking sectors in India. There is huge emerging issue of financial conditions of banking sector in India. But, study is only going to cover selected two private banks and three public banks in India. Foreign Banks have been excluded from the study. As the policies and regulations of Foreign Banks are different from other Commercial Banks they are excluded. The time period is limited from 2016 to 2020. The study may helpful for further descriptive studies on the ideas that will be explored. Moreover, it would be beneficial to gain knowledge regarding maintain the sound financial performance of banking sectors through vary factors.

\section{Sample Size}

Present study contained 05 bank units out of them 03 banks selected from the public sector and rest of 02 banks form new private sector banks randomly.

\subsection{From Public Sector Banks}

1. State Bank of India

2. Bank of Baroda

3. Punjab National Bank

\section{New Private Sector Banks}

1. ICICI Bank Ltd.

2. HDFC Bank Ltd.

\subsection{Period of the Study}

With the purpose of investigate the changing outlook, the study has covered five accounting years which starts from $1^{\text {st }}$ April 2016 to $31^{\text {st }}$ March 2020 for study.

\subsection{Data Collection and Data Sources}

The study based on secondary data, so it has taken from the various available sources. The secondary data collected from the Annual Reports of the selected banks, various publications of RBI such as RBI Bulletins, Banking Statistics-Basic statistical returns, Statistical Tables relating to Banks of India, etc. 


\subsection{Tools of Analysis}

F-test or ANOVA (Analysis of Variances).

F-test is also known as ANOVA, means Analysis of Variances. Where the sample is sub-divided amongst more than two groups at that time ANOVA used.

\section{$\mathbf{F}=\mathrm{MSB} / \mathrm{MSW}$ \\ MSB = Mean Square between Groups \\ MSW = Mean Square within Groups}

The calculated value of ' $\mathrm{F}$ ' is greater than the table value. The Null Hypothesis is rejected and Alternative Hypothesis is accepted.

The calculated value of ' $\mathrm{F}$ ' is smaller than the table value. The Null Hypothesis is accepted and Alternative Hypothesis is rejected.

The concept of profitability and research into its measurement is well advanced within finance and management fields. Recently a well-judged technique named ANOVA Test is widely used for evaluating performance of financial institutions, especially to banks. Profitability of the banking sector under ANOVA Test involves analysis and evaluation of various dimensions of banking operations. Thus ANOVA consists of a set of performance measures that give a comprehensive view of the banks.

\subsection{Variables of the Study}

\subsubsection{Profitability Ratios}

- Interest Spread Ratio.
- Return on Assets.

- Return on Net Worth.

- $\quad$ Earning Per Share.

- Return on Long Term Fund.

\section{Efficiency Ratios}

- $\quad$ Operating Expenses to Total Funds Ratio.

- Non Interest Income to Total Funds.

- Investment Deposit Ratio.

- $\quad$ Profit Per Employee.

- Interest Income/Total Funds Ratio.

\section{Hypothesis Testing and Results}

\subsection{Interest Spread Ratio}

Table 1 reflects that average interest spread ratio of selected public vis a vis private sector banks during study period of 5 years from 2016-2020. Average ratio of selected public as well as private sector banks depicted fluctuating trend during the study period. Highest average interest spread of public sector group was recorded $6.58 \%$ in 2020 while in private sector group was 7.18\% in 2016. Overall Average interest spread of selected public sector banks during sample period stands to 6.40 and that of selected private sector banks that was 7.03 . Hence selected private sector banks show 0.63 higher growth in average interest spread as compared to selected public sector banks. Overall average interest spread indicates that the private

Table 1. Interest spread ratio of the selected public and private sector banks

\begin{tabular}{|c|c|c|c|c|c|c|c|}
\hline & \multicolumn{4}{|c|}{ Public Sector Banks } & \multicolumn{4}{c|}{ Private Sector Banks } \\
\hline & SBI & BOB & PNB & AVG & ICICI & HDFC & AVG \\
\hline 2016 & 6.01 & 6.52 & 6.26 & 6.26 & 6.83 & 7.52 & 7.18 \\
\hline 2017 & 6.36 & 6.77 & 6.39 & 6.51 & 6.58 & 7.46 & 7.02 \\
\hline 2018 & 6.65 & 6.18 & 6.36 & 6.40 & 6.43 & 7.78 & 7.11 \\
\hline 2019 & 6.45 & 6.5 & 6.42 & 6.46 & 6.36 & 7.2 & 6.78 \\
\hline 2020 & 6.59 & 6.49 & 6.58 & 6.55 & 7.15 & 7.02 & 7.09 \\
\hline Average & 6.41 & 6.49 & 6.40 & 6.44 & 6.67 & 7.40 & 7.03 \\
\hline S.D & 0.25 & 0.21 & 0.12 & 0.19 & 0.32 & 0.29 & 0.31 \\
\hline C.V (\%) & 3.93 & 3.23 & 1.82 & 2.99 & 4.85 & 3.98 & 4.41 \\
\hline
\end{tabular}


Table 1 (A). Analysis of ' $F$ ' Test in selected banks under the study interest spread ratio

\begin{tabular}{|c|c|c|c|c|c|c|}
\hline $\begin{array}{c}\text { Source of } \\
\text { Variation }\end{array}$ & SS & df & MS & Fc & Ft & Result \\
\hline $\begin{array}{c}\text { Between } \\
\text { Groups }\end{array}$ & 1.9 & 04 & 0.47 & 3.13 & 2.87 & Fc Ft \\
\hline Within Groups & 3.09 & 20 & 0.15 & & Accepted \\
\hline Total & 4.99 & 24 & & & \\
\hline
\end{tabular}

sector group performing well as compared to public sector group in maintaining profitability during that period. During the study period standard deviation of selected public sector banks was recorded 0.19 , while in selected private sector banks it was 0.31 . Co-efficient of variance of selected public sector banks was 2.99 percent and that of selected private sector banks it was 4.41 percent. It indicates that trend in ratio of private sector banks show higher fluctuation as compared to public sector group during that period.

\section{Hypothesis:}

$\mathrm{H} 0=$ There is no significant difference between Interest Spread Ratio in selected banks under the study.

$\mathrm{H} 1$ = There is significant difference between Interest Spread Ratio in selected banks under the study.

\section{Return on Assets}

Table 2 is depicting average return on assets of selected public vis a vis private sector banks for the study period. Table 2 shows negative trend in average ratio of public sector group while in private sector group it was positive during whole period of study, continuously increased during first three years, marginally declined in 2019, but increased in 2020. Average return on assets of public sector banks was recorded $-0.24 \%$ and that of selected private sector banks it was $1.92 \%$, hence selected private sector banks shown $1.18 \%$ higher growth in average return on assets which indicates batter performance of selected private sector group as compare to public sector group. The positive average ratio of public sector group was recorded $0.27 \%$ in 2017 and $0.16 \%$ in 2020 , that of private sector group it was heights $2.01 \%$ in 2020. During the study period standard deviation of public sector banks was recorded 0.59 as compared to 0.05 of private sector banks. The co-efficient of variance of public sector banks was recorded $142.73 \%$ as compared to $2.74 \%$ in selected private sector banks indicates that fluctuation

Table 2. Return on assets of the selected public and private sector banks

\begin{tabular}{|c|c|c|c|c|c|c|c|}
\hline & \multicolumn{4}{|c|}{ Public Sector Banks } & \multicolumn{3}{c|}{ Private Sector Banks } \\
\hline & SBI & BOB & PNB & AVG & ICICI & HDFC & AVG \\
\hline 2016 & 0.46 & -0.78 & -0.61 & -0.31 & 1.49 & 1.89 & 1.89 \\
\hline 2017 & 0.41 & 0.2 & 0.19 & 0.27 & 1.35 & 1.88 & 1.88 \\
\hline 2018 & -0.91 & -0.34 & -1.6 & -0.95 & 0.87 & 1.93 & 1.93 \\
\hline 2019 & 0.02 & 0.06 & -1.25 & -0.39 & 0.39 & 1.9 & 1.90 \\
\hline 2020 & 0.38 & 0.06 & 0.04 & 0.16 & 0.81 & 2.01 & 2.01 \\
\hline Average & 0.07 & -0.16 & -0.65 & -0.24 & 0.98 & 1.92 & 1.92 \\
\hline S.D & 0.58 & 0.40 & 0.78 & 0.59 & 0.05 & 0.05 & 0.05 \\
\hline C.V (\%) & 799.87 & -250.62 & -121.04 & 142.73 & 2.74 & 2.74 & 2.74 \\
\hline
\end{tabular}


Table 2 (A). Analysis of 'F' Test in Selected Banks under the Study Return on Assets

\begin{tabular}{|c|c|c|c|c|c|c|}
\hline $\begin{array}{c}\text { Source of } \\
\text { Variation }\end{array}$ & SS & df & MS & Fc & Ft & Result \\
\hline $\begin{array}{c}\text { Between } \\
\text { Groups }\end{array}$ & 16.4 & 04 & 4.1 & 8.72 & 2.87 & \multirow{2}{*}{$\begin{array}{c}\text { Fc }>\text { Ft } \\
\text { H1 } \\
\text { Accepted }\end{array}$} \\
\hline Within Groups & 9.56 & 20 & 0.47 & & & \\
\hline Total & 25.96 & 24 & & & \\
\hline
\end{tabular}

in trend of public sector group was much higher as compared to private sector group. Private sector group has performing well in maintaining stability in return on assets as compared to public sector group.

\section{Hypothesis:}

$\mathrm{HO}=$ There is no significant difference between Return on Assets in selected banks under the study.

$\mathrm{H} 1=$ There is significant difference between Return on Assets in selected banks under the study.

\section{Return on Net Worth}

Table 3 shows return on net worth of selected public vis a vis private sector banks during the period from 20162020. Average return on net worth of public sector banks shown negative trend during most of the years under study while average ratio of private sector banks shows mixed trend during the study period. The highest average ratio of public sector banks was recorded 4.53\% in 2017 while in private sector bank it was $14.05 \%$ recorded in 2016. The overall average return on net worth of selected public sector banks was recorded $-4.03 \%$ and that of private sector group it was $11.72 \%$, which is significantly higher in private sector banks as compared to public sector group during the study period.

Standard deviation of the public sector banks was recorded 9.06 and of private sector banks, that was 2.13 during the study period. Co-efficient of variance of private sector banks was recorded $24.22 \%$ while in public sector banks that was $-77.47 \%$. It indicates that private sector banks has more stability in maintaining trend of return on net worth as compare to public sector banks during that period.

\section{Hypothesis:}

$\mathrm{H} 0=$ There is no significant difference between Return on Net Worth in selected banks under the study.

Table 3. Return on net worth of the selected public and private sector banks

\begin{tabular}{|l|l|l|l|l|l|l|l|}
\hline & \multicolumn{9}{|l}{ Public Sector Banks } & \multicolumn{2}{l|}{ Private Sector Banks } \\
\hline & SBI & BOB & PNB & AVG & ICICI & HDFC & AVG \\
\hline 2016 & 6.89 & -13.42 & -11.2 & -5.91 & 11.19 & 16.91 & 14.05 \\
\hline 2017 & 6.69 & 3.43 & 3.47 & 4.53 & 10.11 & 16.26 & 13.19 \\
\hline 2018 & -3.37 & -5.6 & -32.85 & -13.94 & 6.63 & 16.45 & 11.54 \\
\hline 2019 & 0.43 & 0.94 & -24.1 & -7.58 & 3.19 & 14.12 & 8.66 \\
\hline 2020 & 6.95 & 0.76 & 0.58 & 2.76 & 6.99 & 15.36 & 11.18 \\
\hline Average & 3.52 & -2.78 & -12.82 & -4.03 & 7.62 & 15.82 & 11.72 \\
\hline S.D & 4.75 & 6.82 & 15.62 & 9.06 & 3.16 & 1.10 & 2.13 \\
\hline C.V (\%) & 134.98 & -245.53 & -121.84 & -77.47 & 41.46 & 6.98 & 24.22 \\
\hline
\end{tabular}


Table 3(A): Analysis of ' $F$ ' Test in selected banks under the study return on net worth

\begin{tabular}{|c|c|c|c|c|c|c|}
\hline $\begin{array}{c}\text { Source of } \\
\text { Variation }\end{array}$ & SS & df & MS & Fc & Ft & Result \\
\hline $\begin{array}{c}\text { Between } \\
\text { Groups }\end{array}$ & 614.27 & 04 & 153.56 & 0.89 & 2.87 & \multirow{2}{*}{$\begin{array}{c}\text { Fc }<\text { Ft } \\
\text { H0 } \\
\text { Accepted }\end{array}$} \\
\hline Within Groups & 3017.7 & 20 & 150.88 & & & \\
\hline Total & $3,631.97$ & 24 & & & & \\
\hline
\end{tabular}

$\mathrm{H} 1=$ There is significant difference between Return on Net Worth in selected banks under the study.

\section{Earning Per Share}

Table 4 reflects earning per share of selected public vis a vis private sector banks. The average earning per share of selected public sector banks was recorded -47.56 per share as compared to 22.33 per share average that of selected private sector banks. It was much per share higher in private sector group. The earning per share of in case of all the public sector banks under study, even average was negative, while it was 37.29 per share in 2018 in private sector banks during that period.
During the study period standard deviation of public sector bank was recorded 30.91 as compared to 16.05 that of private sector banks. Co-efficient of variance of public sector banks was recorded $-250.64 \%$ and that of private sector banks $-313.52 \%$ during the study period. It indicates that there was a much fluctuation in earning per share trend of public sector banks as to private sector banks.

\section{Hypothesis:}

$\mathrm{H} 0=$ There is no significant difference between earning per share in selected banks under the study.

$\mathrm{H} 1=$ There is significant difference between earning per share in selected banks under the study.

Table 4. Earning per share of the selected public and private sector banks

\begin{tabular}{|c|c|c|c|c|c|c|c|}
\hline & \multicolumn{4}{|c|}{ Public Sector Banks } & \multicolumn{3}{c|}{ Private Sector Banks } \\
\hline & SBI & BOB & PNB & AVG & ICICI & HDFC AVG \\
\hline 2016 & 12.57 & -90.75 & -111.68 & -63.29 & -3.34 & 37.86 & 17.26 \\
\hline 2017 & 11.96 & -30.9 & -52.77 & -23.90 & 16.98 & 56.53 & 36.76 \\
\hline 2018 & -7.2 & -64.97 & -152.69 & -74.95 & 8.7 & 65.88 & 37.29 \\
\hline 2019 & 0.81 & -46.7 & -83.22 & -43.04 & -25.28 & 49.68 & 12.20 \\
\hline Average & -2.84 & -55.73 & -84.13 & -47.56 & -2.48 & 47.14 & 22.33 \\
\hline S.D & 18.42 & 23.01 & 51.28 & 30.91 & 16.38 & 15.73 & 16.05 \\
\hline C.V (\%) & -649.68 & -41.29 & -60.96 & -250.64 & -660.41 & 33.37 & -313.52 \\
\hline
\end{tabular}


Table 4 (A). Analysis of 'F' Test in selected banks under the study earning per share

\begin{tabular}{|c|c|c|c|c|c|c|}
\hline $\begin{array}{c}\text { Source of } \\
\text { Variation }\end{array}$ & SS & df & MS & Fc & Ft & Result \\
\hline $\begin{array}{c}\text { Between } \\
\text { Groups }\end{array}$ & $52,421.69$ & 04 & $13,105.42$ & 19.47 & $2.87 \quad$ Fc $>$ Ft \\
\hline Within Groups & $13,124.22$ & 20 & 656.21 & & Accepted \\
\hline Total & $65,545.91$ & 24 & & & \\
\hline
\end{tabular}

\section{Return on Long Term Fund}

Table 5 shows average return on long-term fund of selected public vis a vis private sector banks during the study period. The average return on long-term fund of public sector group shown mixed trend while in private sector group it was decreased in first four years and then after it was increased in next one year. The average ratio of public sector group during sample period stand to $69.50 \%$ and that of private sector banks it was $53.09 \%$, hence selected public sector banks show $16.41 \%$ higher growth in average ratio. The highest average ratio of public sector banks was recorded $183.11 \%$ in 2017 and that of private sector banks it was $60.42 \%$ in 2016 .

Standard deviation of public sector banks was recorded 12.39 as compared to 6.06 of private sector banks during the study period. Co-efficient of variance of public sector banks was recorded $18.72 \%$ while that was $11.63 \%$ in private sector banks during that period. It indicates that private sector banks were more stable in maintaining profitability during the study period.

\section{Hypothesis:}

$\mathrm{H} 0=$ There is no significant difference between Return on Long Term Fund in selected banks under the study.

Table 5. Return on long term fund (\%) of the selected public and private sector banks

\begin{tabular}{|c|c|c|c|c|c|c|c|}
\hline & \multicolumn{4}{|c|}{ Public Sector Banks } & \multicolumn{3}{c|}{ Private Sector Banks } \\
\hline & SBI & BOB & PNB & AVG & ICICI & HDFC & AVG \\
\hline 2016 & 83.57 & 61.25 & 74.36 & 73.06 & 50.29 & 70.54 & 60.42 \\
\hline 2017 & 82.01 & 77.31 & 90.01 & 83.11 & 45.09 & 65.17 & 55.13 \\
\hline 2018 & 66.97 & 58.36 & 36.1 & 53.81 & 38.54 & 62.88 & 50.71 \\
\hline 2019 & 79.55 & 69.62 & 45.64 & 64.94 & 38.13 & 55.57 & 46.85 \\
\hline 2020 & 88.37 & 65.03 & 64.41 & 72.60 & 49.01 & 55.69 & 52.35 \\
\hline Average & 80.09 & 66.31 & 62.10 & 69.50 & 44.21 & 61.97 & 53.09 \\
\hline S.D & 8.01 & 7.46 & 21.69 & 12.39 & 5.70 & 6.42 & 6.06 \\
\hline C.V (\%) & 10.00 & 11.24 & 34.92 & 18.72 & 12.89 & 10.36 & 11.63 \\
\hline
\end{tabular}


Table 5(A). Analysis of ' $\mathrm{F}$ ' Test in selected banks under the return on long term fund

\begin{tabular}{|c|c|c|c|c|c|c|}
\hline $\begin{array}{c}\text { Source of } \\
\text { Variation }\end{array}$ & SS & df & MS & Fc & Ft & Result \\
\hline $\begin{array}{c}\text { Between } \\
\text { Groups }\end{array}$ & $3,290.01$ & 04 & 822.50 & 5.91 & 2.87 & \multirow{2}{*}{$\begin{array}{c}\text { Fc }>\text { Ft } \\
\text { H1 } \\
\text { Accepted }\end{array}$} \\
\hline Within Groups & $2,718.88$ & 20 & 139.09 & & & \\
\hline Total & $6,008.89$ & 24 & & & & \\
\hline
\end{tabular}

$\mathrm{H} 1=$ There is significant difference between Return on Long Term Fund in selected banks under the study.

\section{Operating Expenses to Total Funds Ratio}

Table 6 shows average operating expenses to fund ratio of selected public vis a vis private sector banks for the period from 2016-2020. Table 6 depicted operating expenses to total funds ratio of the selected public and private sector banks shown mixed in average ratio of both public and private sector group during the study period. Average operating expenses to total fund of public sector group was recorded 3.59 and that of selected private sector banks it was 2.82. Hence selected public sector banks show 0.77 higher growths in average operating expenses to total fund as compared to selected private sector banks. The highest average ratio of public sector banks was recorded $3.88 \%$ in 2018 while that of $3.42 \%$ in private sector banks in 2019.

During the study period, standard deviation of public sector banks was recorded 0.71 and for private sector banks that was 0.64. Co-efficient of variance of selected public sector banks was recorded $20.83 \%$ and that of $22.31 \%$ of selected private sector banks, hence selected private sector banks shows $1.48 \%$ higher fluctuation in trend as compare to selected public sector banks. It indicates that selected public sector banks were more stable in maintaining ratio during that period.

\section{Hypothesis:}

$\mathrm{H} 0=$ There is no significant difference between Operating Expenses to Total Funds Ratio in selected banks under the study.

Table 6. Operating expenses to total funds ratio of the selected public and private sector banks

\begin{tabular}{|c|c|c|c|c|c|c|c|}
\hline & \multicolumn{4}{|c|}{ Public Sector Banks } & \multicolumn{3}{c|}{ Private Sector Banks } \\
\hline & SBI & BOB & PNB & AVG & ICICI & HDFC & AVG \\
\hline 2016 & 1.83 & 4.52 & 4.35 & 3.57 & 3.47 & 2.92 & 3.20 \\
\hline 2017 & 1.79 & 4.2 & 3.11 & 3.03 & 1.87 & 2.41 & 2.14 \\
\hline 2018 & 1.86 & 3.98 & 5.79 & 3.88 & 1.96 & 2.3 & 2.13 \\
\hline 2019 & 1.88 & 4.17 & 5.13 & 3.73 & 4.02 & 2.82 & 3.42 \\
\hline 2020 & 3.04 & 5.01 & 3.18 & 3.74 & 3.38 & 3 & 3.19 \\
\hline Average & 2.08 & 4.38 & 4.31 & 3.59 & 2.94 & 2.69 & 2.82 \\
\hline S.D & 0.54 & 0.40 & 1.18 & 0.71 & 0.97 & 0.31 & 0.64 \\
\hline C.V (\%) & 25.85 & 9.23 & 27.39 & 20.83 & 32.92 & 11.70 & 22.31 \\
\hline
\end{tabular}


Table 6(A). Analysis of ' $F$ ' Test in selected banks under the operating expenses to total funds ratio

\begin{tabular}{|c|c|c|c|c|c|c|}
\hline $\begin{array}{c}\text { Source of } \\
\text { Variation }\end{array}$ & SS & df & MS & Fc & Ft & Result \\
\hline $\begin{array}{c}\text { Between } \\
\text { Groups }\end{array}$ & 20.85 & 04 & 5.21 & 9.14 & 2.87 & \multirow{2}{*}{$\begin{array}{c}\text { Fc }>\text { Ft } \\
\text { H1 } \\
\text { Accepted }\end{array}$} \\
\cline { 1 - 5 } Within Groups & 11.45 & 20 & 0.57 & & \\
\hline Total & 32.30 & 24 & & & \\
\hline
\end{tabular}

$\mathrm{H} 1=$ There is significant difference between Operating Expenses to Total Funds Ratio in selected banks under the study.

\section{Non Interest Income to Total Funds Ratio}

An analysis of Table 7 shows fluctuating trend in average non-interest income to total fund ratio of both public and private sector group during the study period. Average non-interest income to total fund of public sector group was recorded $1.11 \%$ and that of selected private sector banks it was $1.82 \%$, hence selected private sector banks show $0.72 \%$ higher growths in average non-interest income to total fund as compared to selected public sector banks. The highest average ratio of public sector banks was recorded $1.23 \%$ in 2017 while that of $2.09 \%$ in private sector banks in 2017.

During the period standard deviation of public sector was 0.14 and private sector group was 0.25 . Co-efficient of variance of selected public sector banks was recorded $12.65 \%$ and that of $12.90 \%$ in selected private sector banks, hence selected private sector banks shows higher fluctuation in trend as compare to selected public sector banks. It indicates that selected public sector banks were more stable in maintaining ratio during that period.

\section{Hypothesis:}

$\mathrm{H} 0=$ There is no significant difference between Non Interest Income to Total Funds Ratio in selected banks under the study.

Table 7. Non interest income to total funds ratio of the selected public and private sector banks

\begin{tabular}{|c|c|c|c|c|c|c|c|}
\hline & \multicolumn{4}{|c|}{ Public Sector Banks } & \multicolumn{3}{c|}{ Private Sector Banks } \\
\hline & SBI & BOB & PNB & AVG & ICICI & HDFC & AVG \\
\hline 2016 & 1.26 & 0.74 & 1.09 & 1.03 & 2.25 & 1.65 & 1.95 \\
\hline 2017 & 1.41 & 0.97 & 1.3 & 1.23 & 2.62 & 1.56 & 2.09 \\
\hline 2018 & 1.46 & 0.92 & 1.2 & 1.19 & 2.12 & 1.58 & 1.85 \\
\hline 2019 & 1.04 & 0.84 & 0.96 & 0.95 & 1.58 & 1.53 & 1.56 \\
\hline 2020 & 1.19 & 1.06 & 1.16 & 1.14 & 1.6 & 1.68 & 1.64 \\
\hline Average & 1.27 & 0.91 & 1.14 & 1.11 & 2.03 & 1.60 & 1.82 \\
\hline S.D & 0.17 & 0.12 & 0.13 & 0.14 & 0.44 & 0.06 & 0.25 \\
\hline C.V (\%) & 13.33 & 13.51 & 11.12 & 12.65 & 21.88 & 3.93 & 12.90 \\
\hline
\end{tabular}


Table 7(A). Analysis of ' $\mathrm{F}$ ' Test in selected banks under the non interest income to total funds ratio

\begin{tabular}{|c|c|c|c|c|c|c|}
\hline $\begin{array}{l}\text { Source of } \\
\text { Variation }\end{array}$ & SS & df & MS & Fc & $\mathrm{Ft}$ & Result \\
\hline $\begin{array}{c}\text { Between } \\
\text { Groups }\end{array}$ & 3.84 & 04 & 0.96 & 4.8 & 2.87 & \multirow{3}{*}{$\begin{array}{c}\mathrm{Fc}>\mathrm{Ft} \\
\text { H1 Accepted }\end{array}$} \\
\hline Within Groups & 0.59 & 20 & 0.02 & & & \\
\hline Total & 4.43 & 24 & & & & \\
\hline
\end{tabular}

$\mathrm{H} 1=$ There is significant difference between Non Interest Income to Total Funds Ratio in selected banks under the study.

\section{Investment Deposit Ratio}

Table 8 shows average investment/deposit ratio of selected public vis a vis private sector banks during the study period. The table shows mixed trend in average investment/deposit ratio of public sector group as well as of private sector group during the study period. Average investment/deposit ratio of selected public sector banks during sample period stands to $30.10 \%$ and that of selected private sector banks it was $33.71 \%$, hence selected private sector banks shows $3.61 \%$ higher growths in average investment to deposit as compared to selected public sector banks. The highest average ratio of public sector banks was recorded $31.83 \%$ in 2019 , while in private sector it was $36.95 \%$ in 2016.

Standard deviation of selected public sector banks was recorded 2.72 while that of selected private sector banks stands to 2.36 during the study period. Co-efficient of variance in selected private sector banks was 6.99\%, which was $9.49 \%$ public sector banks. Co-efficient of variance indicates better stability in trend of average investment/deposit of selected public sector banks as compare to selected private sector bank's average during the study period.

\section{Hypothesis:}

$\mathrm{H} 0=$ There is no significant difference between Investment Deposit Ratio in selected banks under the study.

Table 8. Investment deposit ratio of the selected public and private sector banks

\begin{tabular}{|c|c|c|c|c|c|c|c|}
\hline & \multicolumn{4}{|c|}{ Public Sector Banks } & \multicolumn{3}{c|}{ Private Sector Banks } \\
\hline & SBI & BOB & PNB & AVG & ICICI & HDFC & AVG \\
\hline 2016 & 33.26 & 20.98 & 28.54 & 27.59 & 38.06 & 35.84 & 36.95 \\
\hline 2017 & 37.46 & 21.54 & 30.03 & 29.68 & 32.96 & 33.22 & 33.09 \\
\hline 2018 & 33.2 & 27.6 & 31.79 & 30.86 & 36.19 & 30.71 & 33.45 \\
\hline 2019 & 33.22 & 28.54 & 29.9 & 30.55 & 31.82 & 31.75 & 31.79 \\
\hline 2020 & 32.3 & 29.03 & 34.16 & 31.83 & 32.37 & 34.15 & 33.26 \\
\hline Average & 33.89 & 25.54 & 30.88 & 30.10 & 34.28 & 33.13 & 33.71 \\
\hline S.D & 2.04 & 3.94 & 2.16 & 2.72 & 2.71 & 2.01 & 2.36 \\
\hline C.V (\%) & 6.01 & 15.44 & 7.01 & 9.49 & 7.91 & 6.06 & 6.99 \\
\hline
\end{tabular}


Table 8(A). Analysis of ' $\mathrm{F}$ ' Test in selected banks under the investment deposit ratio

\begin{tabular}{|c|c|c|c|c|c|c|}
\hline $\begin{array}{c}\text { Source of } \\
\text { Variation }\end{array}$ & SS & df & MS & Fc & Ft & Result \\
\hline $\begin{array}{c}\text { Between } \\
\text { Groups }\end{array}$ & 278.62 & 04 & 278.62 & 11.19 & 2.87 \\
\hline Within Groups & 124.47 & 20 & 6.22 & & Fc Ft Accepted \\
\hline Total & 403.09 & 24 & & & \\
\hline
\end{tabular}

$\mathrm{H} 1$ = There is significant difference between Investment Deposit Ratio in selected banks under the study.

\section{Profit Per Employee}

Table 9 shows average net profit per employee of selected public vis a vis private sector banks during the study period of 5 years from 2016 to 2020 . The average net profit per employee of selected public sector banks stands to Rs. 1.90 lakh and that of selected private sector banks it was Rs. 14.40 lakh, hence selected private sector banks shows Rs. 12.5 lakh higher growth in net profit per employee. In 2006 and after second year of the study period the ratio of public sector banks shows negative trend while the ratio of private sector banks shows an increasing trend during first dour years and then after it was decreased but increased again next year, i.e., in 2020 it increased and reached to heights of the study period.

The standard deviation of public sector banks was recorded 13.07 and that of private sector banks it was 3.97 during that period. Co-efficient of variance of public sector banks was recorded $-247.10 \%$ and that of private sector banks it was $31.49 \%$. Higher co-efficient of variation of public sector banks indicates much fluctuation in trend of average net profit per employee of public sector banks as compared to private sector banks which results into less consistency in efficiency of public sector banks during that period.

Hypothesis:

$\mathrm{H} 0=$ There is no significant difference between Profit Per Employee in selected banks under the study.

Table 9. Profit per employee of the selected public and private sector banks (In Rupees Per Lakh)

\begin{tabular}{|c|c|c|c|c|c|c|c|}
\hline & \multicolumn{4}{|c|}{ Public Sector Banks } & \multicolumn{3}{c|}{ Private Sector Banks } \\
\hline & SBI & BOB & PNB & AVG & ICICI & HDFC AVG \\
\hline 2016 & 4.7 & -10 & -6 & -3.77 & 14 & 15 & 14.5 \\
\hline 2017 & 5.11 & 3 & 2 & 3.37 & 12 & 16 & 14 \\
\hline 2018 & -2.43 & -4 & -17 & -7.81 & 8 & 20 & 14 \\
\hline 2019 & 0.33 & 8 & -15 & -2.22 & 4 & 23 & 13.5 \\
\hline 2020 & 5.79 & 1 & 53 & 19.93 & 8 & 24 & 16 \\
\hline Average & 2.70 & -0.40 & 3.40 & 1.90 & 9.20 & 19.60 & 14.40 \\
\hline S.D & 3.58 & 6.88 & 28.75 & 13.07 & 3.90 & 4.04 & 3.97 \\
\hline C.V (\%) & 132.62 & -1719.37 & 845.45 & -247.10 & 42.38 & 20.60 & 31.49 \\
\hline
\end{tabular}


Table 9(A). Analysis of ' $\mathrm{F}$ ' Test in selected banks under the profit per employee ratio

\begin{tabular}{|c|c|c|c|c|c|c|}
\hline $\begin{array}{c}\text { Source of } \\
\text { Variation }\end{array}$ & SS & df & MS & Fc & Ft & Result \\
\hline $\begin{array}{c}\text { Between } \\
\text { Groups }\end{array}$ & $1,248.8$ & 04 & 312.2 & 1.72 & 2.87 & \multirow{2}{*}{$\begin{array}{c}\text { Fc }<\text { Ft } \\
\text { H0 } \\
\text { Accepted }\end{array}$} \\
\cline { 1 - 5 } Within Groups & $3,616.12$ & 20 & 180.80 & & & \\
\hline Total & 4.864 .92 & 24 & & & & \\
\hline
\end{tabular}

$\mathrm{H} 1=$ There is significant difference between Profit Per Employee in selected banks under the study.

\section{Interest Income/Total Funds Ratio}

Table 10 shows average net interest income to total assets of selected public vis a vis private sector banks during the study period. Analysis of Table 10 shows declined trend in average net interest income to total assets ratio of both public and private sector group during the study period. The average net interest income to total assets of selected public sector banks stands to $6.74 \%$ and that of selected private sector banks it was $7.91 \%$, hence selected private sector banks shows $0.82 \%$ higher growth in net interest income to total assets during the study period. The overall average ratio of private sector banks was remains higher as compared to public sector group indicates better performance of private sector group in generating interest income as compared to public sector group.

The standard deviation of public sector banks and private sector banks were recorded 0.30 and 0.41 respectively during the study period. Co-efficient of variance of public sector banks was recorded $4.44 \%$ and that of private sector banks was $5.15 \%$, which were almost equal. It indicates that in both public and private sector group variation in trend were remains same during that period.

\section{Hypothesis:}

$\mathrm{H} 0=$ There is no significant difference between Interest Income/Total Funds Ratio in selected banks under the study.

Table 10. Interest income/total funds ratio of the selected public and private sector banks

\begin{tabular}{|c|c|c|c|c|c|c|c|}
\hline & \multicolumn{4}{|c|}{ Public Sector Banks } & \multicolumn{3}{c|}{ Private Sector Banks } \\
\hline & SBI & BOB & PNB & AVG & ICICI & HDFC & AVG \\
\hline 2016 & 7.44 & 6.56 & 7.49 & 7.16 & 7.73 & 9.27 & 8.50 \\
\hline 2017 & 6.98 & 6.07 & 6.85 & 6.63 & 7.29 & 8.81 & 8.05 \\
\hline 2018 & 7.22 & 6.06 & 6.49 & 6.59 & 6.68 & 8.32 & 7.50 \\
\hline 2019 & 6.85 & 6.37 & 6.69 & 6.64 & 6.9 & 8.57 & 7.74 \\
\hline 2020 & 6.79 & 6.56 & 6.74 & 6.70 & 7.27 & 8.27 & 7.77 \\
\hline Average & 7.06 & 6.32 & 6.85 & 6.74 & 7.17 & 8.65 & 7.91 \\
\hline S.D & 0.27 & 0.25 & 0.38 & 0.30 & 0.40 & 0.41 & 0.41 \\
\hline C.V (\%) & 3.84 & 3.94 & 5.54 & 4.44 & 5.62 & 4.73 & 5.18 \\
\hline
\end{tabular}


Table 10(A). Analysis of ' $F$ ' Test in selected banks under the interest income/total funds ratio ratio

\begin{tabular}{|c|c|c|c|c|c|c|}
\hline $\begin{array}{c}\text { Source of } \\
\text { Variation }\end{array}$ & SS & df & MS & Fc & Ft & Result \\
\hline $\begin{array}{c}\text { Between } \\
\text { Groups }\end{array}$ & 14.99 & 04 & 3.74 & 34 & 2.87 & $\begin{array}{c}\text { Fc Ft Accepted } \\
\text { Within Groups }\end{array}$ \\
\hline Total & 17.29 & 20 & 0.11 & & \\
\hline
\end{tabular}

$\mathrm{H} 1=$ There is significant difference between Interest Income/Total Funds Ratio in selected banks under the study.

\section{Observations}

- It has been observed and derived from the analysis that.

- The selected private sector banks shows higher interest spread with comparatively higher deviation from its average as compared to selected public sector banks.

- The selected private sector banks maintains higher return on assets which indicates better profitability performance of these banks as compared to public sector banks.

- Profitability of selected private sector banks based on net worth was much higher with batter stability during period under study.

- The average earning per share of private sector banks was much better with better stability in trend during period under study.

- The average operating cost of selected public sector banks were comparatively less which result in to higher profit margin during period under study

- The average non-interest income of selected public sector banks were comparatively more as compared to private sector group.

- The average non-interest income of selected public sector banks was comparatively more as compared to private sector group.

- The selected private sector banks maintains higher investment/deposit ratio with comparatively high deviations from its average in comparison to selected public sector banks.

- Profit per employee of private sector bank, as compared to public sector banks, is much higher which shows that these banks were performing well by utilising maximum human resource with better consistency which result in to more profit per employee engaged in the business.

- The selected private sector banks were performing well by generating more net interest income as compare to public sector banks with better consistency which result in to more profit margin in the business.

\section{Conclusion}

Private sector banks are in quite comfortable position in maintaining profitability in business as compared to public sector banks. Overall performance of private sector group was much batter in generating profit against assets invested by banks as compared to selected public sector banks. Earnings per share in case of private sector banks were more as compared to public sector banks with less fluctuation in trend during the study period. The selected public sector banks were lending more to corporate sector because of lower operating cost while private sector banks focused on retail lending. So public sector banks working more efficiently as compared to private sector group. Public sector banks working more efficiently as compared to private sector because of comparatively more non-interest income. The performance of private sector banks increasing year after year in utilizing maximum human resource efficiently which indicates better future 
condition will lead into low cost and better profitability of private sector group. The overall interest income ratio of private sector banks was remained higher because of generating interest income.

There is significant difference found between interest spread ratio, return on assets, earning per share, return on long term fund, operating expenses to total funds ratio, non interest income to total funds ratio, investment deposit ratio and interest income/total funds ratio in selected banks under the study. There is no significant difference found between return on net worth and profit per employee in selected banks under the study.

\section{References}

Abdulkareem, A. M. (2020). Profitability performance of HDFC Bank and ICICI Bank: An Analytical and Comparative Study. Global Journal of Management and Business Research, 20(1). ISSN (Online) 2249-4588, 0975-5853 (print).

Agarwal, P. (2019). Profitability of Indian Public and Private Sector Banks: A Comparative Study. IJRAR, 6(1):919927.

Dixit, D. (2016). Performance analysis of private sector and public sector banks with reference of ICICI Bank and State Bank of India. International Journal of Applied Research, 2(9):443-449.

Guruswamy, D. (2012). Analysis of profitability performance of State Bank of India and its Associates. ZENITH International Journal of Business Economics and Management Research, 2(1). ISSN (Online) 2249-8826.

Gupta, A., \& Sundram, V. S (2015). Comparative study of public and private sector banks in India: An empirical Analysis.
International Journal of Applied Research, 1(12):895901.

Jindal, S. (2016). Commercial Banks in India: Profitability growth and development. International Journal of Engineering and Management Research, 6(3):364-370.

Kathhiriya, J. G., \& Shah, P. (2018). A study on profitability of selected private banks of India. International Journal of Research in all Subjects in Multi Languages, 6(5):5-10.

Kawshala, H., \& Panditharathna, K. (2017). The factors effecting on bank profitability. International Journal of Scientific and Research Publications, 7(2).

Kaur, A. (2012). An empiricl study on the performance evaluation of public sector banks in India. International Journal of Marketing, Financial Services and Management Research, 1(11). ISSN 2277-3622.

Nedunchezhian, V. R. \& Premalatha, K. A. (2016). Comparison of financial performance in the banking sector: Some evidence from Indian Public Sector Banks. International Journal of Trend in Research and Development, 3(3). ISSN: 2394-9333

Saluja, R., \& Pallavi. (2017). Profitability analysis of scheduled commercial banks in India”. IJARIIE, 3(3):3431-3437.

Sharma, D. (2013). Efficiency and productivity of banking sector: A critical analysis. Journal of Applied Finance \& Banking, 4(1). ISSN: 1792-6599 (Online) 1792-6590 (print).

Singh, Y. (2018). Profitability of Indian Scheduled Commercial Banks: A comparative evaluation. Amity Journal of Finance, 3(1):81-88.

Singh, A. K. 2015). An analysis of profitability position of Private Bank in India. International Journal of Scientific and Research Publications, 5(5):1-11. 